\title{
Development of Community Potentials in Management of Sustainable Peatlands
}

\author{
Zulkarnaini, Abdul Sadad \\ Program Study of Public Administration FISIP University of Riau, Pekanbaru
}

\begin{abstract}
Tanjung Leban Village, Bukit Batu District, Bengkalis Regency, Riau Province is a village included in the Rokan-Siak Kecil River Peat Hydrology Unit. The existence of this village is very strategic in maintaining the peat swamp ecosystem because its area is included in the Giam Siak Kecil-Bukit Batu Biosphere Reserve area (GSK-BB). But his condition today is quite alarming because it is included in an area prone to repeated land and forest fires. Departing from the above problems, the author wants to raise the focus of the research problem on efforts to develop community potential in peatland management. This study aims to analyze the development of community potential in peatland management in Tanjung Leban Village. This research is a qualitative descriptive study with a sampling technique used is snowball sampling. Research informants are all stakeholders involved and responsible for peatland management. Data collection is done by interviewing, observing, and studying documentation. After the data is collected then it is analyzed using qualitative descriptive analysis. The results showed that the fundamental problem related to environmental management at the study site was the threat of land and forest degradation due to the use of peatland ecosystems that had not been integrated. Therefore it is important to have an empowerment effort with the main goal of improving the quality of life of the community, this is because community empowerment is believed to be able to motivate to change for the better so as to improve the socioeconomic of the family, foster a work culture, and foster a passion for cooperation in development. The programs that are needed by people who live around peatlands are environmental education, the application of environmentally friendly technologies, and the socialization of regulations relating to the protection of ecosystems.
\end{abstract}

\section{Keywords:}

community development, ecosystem utilization, peatlands

\section{Introduction}

Communities living in the area of living peatlands are actually in fragile ecosystems (Najiyati, 2005). Called fragile because of the marginal conditions of peatlands which causes most people to experience poverty. That is why their existence is between poverty and a damaged ecosystem, like two sides of a coin that cannot be separated. On one hand they have a very large dependence on these ecosystems, on the other hand their knowledge is minimal for the utilization of environmentally friendly ecosystems (Agus, et al, 2011). Add to this the fact that not many people pay attention to their helplessness today. 
Data states that the use of ecosystems in some peatland areas in Riau is indeed of concern because it is often exploited and destructive (Noor, 2016). No exception to protected areas such as the Giam Siak Kecil-Bukit Batu Biosphere Reserve (GSK-BB) which is located in three regions, namely Bengkalis, Siak, and Dumai Regencies. Many activities carried out in this area are the conversion of land into agricultural land, plantations, and forestry, as well as settlement. During the 2010-2014 period around biosphere reserves, the area of monoculture plantations (oil palm and rubber) increased from 667.76 Ha to 1,198.73 Ha and mixed gardens also increased from 3,674.48 Ha to 6,580.02 Ha (Rushayati, et al ,2014).

This exploitative use of peatlands in the biosphere reserve continues to this day. Even this condition was allegedly triggered a large forest and land fires in Riau, especially in 2014-2017. According to NASA Active Fire Point data on the Global Forest Watch Fires platform (2017), half of hot spot warnings in Riau Province occur in protected areas, including the GSK-BB Biosphere Reserve. And around 38 percent of fire alerts in Riau Province are located on peatland locations that are rich in carbon stocks and can release greenhouse gases into the atmosphere which are increasingly triggering global climate change (Sutikno, et al, 2018).

In terms of trends, peatland fires from year to year in this landscape occur in the same area or around previous events. The dominant factor causing peatland fires is the damage to the hydrological conditions of the area (Sutikno, et al, 2018). These fires are not only on the company's land area, but also on community plantations. During 2011-2015 the number of detected hotspots amounted to 9,215 in the GSK-BB Biosphere Reserve consisting of 4,714 transition zones, 3,504 buffer zones, and 999 core zones (Terra-Aqua Modis BMKG Satellite, 2016). What is ironic from the data above is that the hotspots do not only appear in the transition and buffer zones which are intended as cultivation areas, but also occur in the core zone which is a protected area.

Tanjung Leban Village Bandar Laksamana District Bengkalis Regency is a village within the buffer zone zone of the GSK-BB Biosphere Reserve. Qomar (2017) states, Tanjung Leban Village is the location that has experienced the most frequent land fires in the last 12 years. This allegedly happened because this area has high accessibility, a lot of new land clearing for community oil palm plantations, and peatlands have been drained. If the 
drained peatlands experience a fire, it is very difficult to extinguish because the fuel is abundant and the fire occurs below the surface of the land (Darmawan, 2012).

Learning from experience in the Maya Biosphere Reserve in Guatemala, management of concession areas within a biosphere reserve must be an ongoing adaptive process, taking into account internal dynamics and external factors, and must bridge the social, ecological, and economic domains (Radachowsky, et al, 2012). Exploitative use will cause the ecosystem to experience degradation in quantity and quality which will reduce its ecological and economic functions.

Coupled with the many interests of various parties who use ecosystems often lead to conflict and lead to management with narrow considerations. This condition is exacerbated by the lack of real attention and activities on ecosystem management carried out by the government and NGOs, which makes the use of these ecosystems is very dangerous to the sustainability of the lives of the surrounding communities in the future (Zulkarnaini, 2018). If the management of the peatland ecosystem is not done wisely, it will cause damage to the ecosystem itself and the resources contained therein as well as to reduce the welfare of the people who depend on the ecosystem (Gunarso, et al, 2013). So the need for efforts to develop the potential of the community with the main goal is to improve the quality of life of the community itself. This is due to the fact that community empowerment is believed to be able to motivate to change for the better so as to improve the socioeconomic family, foster a work culture, and foster a spirit of cooperation in development (Rohmah, 2014).

The pattern of community development on peatlands needed in the future is to uphold the aspirations and potential of the community to carry out self-help activities (Permatasari, 2014). The form is a bottom-up intervention that respects and recognizes that the lower classes have the potential to meet their needs, solve problems, and be able to do productive business with the principles of self-help and togetherness (Sulistiyani, 2004). From this thought it can be stated, the good and bad of the ecosystem can not be separated from the people who live in the area, meaning that the community has an important role for the preservation of the peatland ecosystem. 


\section{Method}

This research uses qualitative methods to describe (descriptive) and explain (explanatory) about the development of community potential in peatland management in Tanjung Leban Village, Bukit Batu District, Bengkalis Regency. The reason for choosing a qualitative method is the direct desire of the writer to recognize the problem and obtain justification for the situation and practices that are taking place in the field. The goal is to be able to verify and then get results for making plans in the future so that the results are even better (Sugiyono, 2006). The village of Tanjung Leban was chosen as the research location because this village is located within the buffer zone zone of the GSK-BB Biosphere Reserve which has deep peatlands. For the GSK-BB Biosphere Reserve area, this village is the location that has experienced the most frequent land fires in the last 12 years. Even the fires occurred repeatedly in the same place and time. This is thought to have happened because the village has high accessibility, a lot of new land clearing for community and company oil palm plantations, and the peatlands have been irregularly drained.

\section{Results and Discussion}

\section{Existing Condition of Peatland Utilization}

Tanjung Leban Village is one village that has a wide enough area, namely 2016 KM2. This relatively new village is located on the border of the Bengkalis Regency Government and the Dumai City Government, therefore the level of accessibility is quite high. Population growth is progressing at a moderate level of intensity, where by 2018 the population was 2,039 out of 530 households consisting of 1029 men and 980 women. The village area consists of three hamlets, namely Bakti Hamlet, Air Raja Hamlet, and Bukit Lengkung Hamlet, and is equipped with 5 RWs and 11 RTs that function to maintain the stability of social life in the community.

Tanjung Leban Village is a village that is developing quite quickly in Bandar Laksamana District. Village income from the Village Budget (APBD) in 2018 reaches Rp 2.9 billion. The income of the population includes the results of oil palm plantations, rubber, fishermen and independent businesses. The ethnic groups who live are predominantly Malay and the daily language of the population interacts using coastal Malay. There are also other tribes, namely Javanese, Chinese, and Bataks. The religion of the population including, 
Islam as a majority, Christianity, and Buddhism. Although the life of the community is quite heterogeneous, the social life of the community has been quite well maintained. Where among the people who have tribal differences while maintaining harmony and peace.

Besides being surrounded by a plantation area, part of the village is located on the edge of the sea. Therefore, besides having potential in the plantation sector, Tanjung Leban Village also has the potential to be developed as a tourist destination area. Where the maritime tourism area of this village has a very beautiful coastline, long with white sand along the coast. This condition is coupled with the presence of mangrove ecotourism in some coastal areas. In the marine tourism area, concrete roads, rock piles, cleaners, gazebos, electricity networks and clean water facilities have been built. The development of marine tourism facilities carried out aims to develop the tourism potential contained. In addition, the use of marine tourism areas is carried out to develop fisheries production that is around the sea and as an attraction for people who visit.

Clearing of peatlands in Tanjung Leban by the community began in 1992 with the main commodity planted in rubber (Arifudin, 2018). The history of land clearing was begun by the Industrial Plantation Forest Company (HTI). After being opened access by the HTI Company, the community then demanded their rights. Thanks to their demands, part of the land was given to the community to process and control it. But after they owned the land, the land that was acquired was eventually sold to other people who generally did not live there.

Initially, community rubber plantations developed well and became the main economic source in meeting the needs of life. But the existence of rubber plantations began to erode after the price of rubber fluctuated. The price of rubber continues to plummet, so people must find other ways to survive in meeting their daily needs. This phenomenon then became one of the causes of the community converting rubber plantations into oil palm plantations.

Oil palm is slowly becoming the belle of interest by people who are talkative to plant oil palm. The problem is that the land planted with oil palm is deep enough peat so that new problems emerge and become a scourge for the community. Peatlands that have been planted with oil palm experience drought and are highly flammable. After the fire, some 
residents no longer worked their land and are still left as idle lands until now. This sleeping land is then often burned in the dry season.

\section{Development of Community Potential in Peatland Management}

People who live and live in the peatland area of Tanjung Leban Village in general have limited economic standards. For example, having a relatively small savings, both in the form of production, goods, or money. Their education is low, because they are far from school or lack of financial support to continue their education at school. In such conditions, they need additional knowledge and skills through ongoing training that can be done while working.

No less the efforts of the government and other parties to reduce the long-term adverse effects of development on peatlands, including those related to environmental change issues (Noor, 2007). But at the same time, there is also no less government policy accompanied by the powerlessness of law enforcement and community ignorance which then spur damage in the long run. It is not always easy to divide the attention between economic interests and environmental interests, especially when Indonesia is in a condition of dire need of investment and a driver of development, although at the same time Indonesia has stated to adopt the concept of sustainable development.

The most pressing issue for the poor and underdeveloped is the unavailability of economic opportunities and sustainable livelihoods. Therefore, community empowerment on peatlands must be able to increase the community's ability to optimize the utilization of economic potential and natural resources without damaging the environment.

The limited economic carrying capacity of peatlands in terms of agriculture, must be a challenge in finding other potential so that people have the choice of a decent and environmentally friendly livelihood source. Thus, increasing economic capacity must also be accompanied by increased awareness of environmental sustainability. Without that, improving economic conditions can actually turn into a destructive factor because it can be a capital for some people who are not aware to do more damage to the environment.

Community development on peatlands must be able to improve the community's ability to optimize the use of economic potential and natural resources without damaging the environment (Zulkarnaini, 2018). The limited economic carrying capacity of peatlands in 
terms of agriculture, must be a challenge in finding solutions so that the community has a decent and environmentally friendly livelihood choice. Thus, increasing economic capacity must also be accompanied by increased awareness of environmental sustainability. Without that, improving economic conditions can actually turn into a destructive factor because it can be a capital for some people who are not aware to do more damage to the environment. The main livelihood support provided is in the form of facilitation in identifying alternative livelihoods for the community, as well as providing technical and financial support to realize these alternatives. Technical support includes providing information on land suitability for certain activities, silvicultural techniques, hydrological information and marketing community products.

Related to providing support, the main mechanism applied is in the form of a biorights mechanism, which is the integration of financial support for community economic activities combined with the raising of awareness of recipient communities to participate in efforts to preserve and maintain the natural processes of the surrounding environment. And if needed, they participate in the process of restoration of damaged peatlands and forests. The whole process is done by placing local partners as the main players in exploring and running the process in the community.

One of the main problems faced by the executors of the empowerment activities is the sustainability of the activities after they had stopped. Very many good initiatives that are carried by an activity then can not be realized fully because of these limitations. On the one hand, the success of the activities of a community-based program tends to require more time because of the demands to carry out the stages of the preparation process and approaches that require a lot of time.

Working with community groups whose members have different abilities to absorb the ideas promoted by the program requires the ability to prepare for equality among group members, and again, this requires adequate time. Meanwhile, on the other side of the program mechanism also has limited time to implement support, so it is necessary to prepare a mechanism that allows continuity of support after the program ends. 


\section{Conclusion}

Existing resources in peatlands are challenges and opportunities that can encourage the development of community potential in the village of Tanjung Leban. This potential can be developed while still based on local knowledge that considers the carrying capacity of the environment. This is done by paying attention to the slices between the conditions of the existing ecosystem, how to involve community participation, and direct it to develop as part of improving the people's economy. The carrying capacity of the peat ecosystem environment is realized as a potential that can become an investment, then by involving community participation a process is carried out to find a meeting point in order to develop the economy of the village community. Therefore, all parties must pay close attention to the people who have taken care of the peatland ecosystem through empowerment activities. Community empowerment on peatlands must be funded by everyone who enjoys direct or indirect benefits of peatland sustainability.

\section{References}

Agus, F., Anda, M., Jamil, A., \& Masganti. 2014. Lahan Gambut Indonesia: Pembentukan, Karakteristik, dan Potensi Mendukung Ketahanan Pangan. Jakarta: IAARD Press bekerjasama Badan Penelitian dan Pengembangan Pertanian Kementerian Pertanian RI.

Arifudin, Almasdi Syahza, Osamu Kozan, Kei Mizuno, Kosuke Mizuno, Zuli Laili Isnaini, Wahyu Iskandar, Sunawiruddin Hadi, Asnawi, Ayu Aizatul Natasya, Hasrullah, 2019. Dinamika Penggunaan, Kebakaran, dan Upaya Restorasi Lahan Gambut: Studi Kasus di Desa Tanjung Leban, Bengkalis, Unri Conference Series: Agriculture and Food Security 1: 40-45

CIMTROP, 2006. Rehabilitasi dan Pengelolaan Lahan Gambut Eks PLG di Kalimantan Tengah. Palangkaraya: CIMTROP dan Universitas Palangkaraya.

Darmawan, Budi. 2015. Rancang Bangun Model Pencegahan Kebakaran Ekosistem Hutan Rawa Gambut. Pekanbaru: Pascasarjana Universitas Riau.

Huraerah, Abu. 2011. Pengorganisasi dan Pengembangan Masyarakat: Model dan Strategi Pembangunan Berbasis Kerakyatan. Bandung: Humaniora - IKAPI. 
Kementerian Lingkungan Hidup RI. 2012. Strategi Nasional Pengelolaan Lahan Gambut Berkelanjutan. Jakarta.

Najiyati, Sri., Agus A., I Nyoman N.S., 2005. Pemberdayaan Masyarakat di Lahan Gambut. Bogor: Wetlands International.

Noor, Muhammad. 2016. Debat Gambut; Ekonomi, Ekologi, Politik, dan Kebijakan. Yogyakarta: Gadjah Mada University Press.

Nugrianti, Oni dan Zulkarnaini. 2013. Pemberdayaan Masyarakat Melalui Program Alokasi Dana. Jurnal Kebijakan Publik. Vol. 4, No. 1

Osaki M., Nursyamsi D., Noor M., Wahyunto, Segah H. 2016. Peatland in Indonesia. In: Osaki M., Tsuji N. (eds). Tropical Peatland Ecosystems. Tokyo: Springer.

Pranarka dan Onny S. Prijono., 1996., Pemberdayaan: Konsep, Kebijakan dan Implementasi., Jakarta: CSIS.

Pramana Y. 2012. “Bentuk dan Tingkat Partisipasi Stakeholder dalam Pengelolaan Cagar Biosfer Giam Siak Kecil-Bukit Batu Provinsi Riau". Tesis. Bogor: Institut Pertanian Bogor.

Qomar, Nurul. 2017. Kebijakan Pengelolaan Sumberdaya Cagar Biosfir Giam Siak KecilBukit Batu Provinsi Riau. Bogor: Pascasarjana IPB

Rohmah, Siti. 2014. “Model Pemberdayaan Ekonomi Perempuan Melalui Grassroot Microfinance Syariah" Jurnal SAWWA - Volume 10, Nomor 1.

Radachowsky J, Ramos VH, McNab R, Baur EH, Kazakov N. 2012. Forest concessions in the Maya Biosphere Reserve, Guatemala: a decade later. Forest Ecology and Management 268:18-28.doi:10.1016/j.foreco.2011.08. 043.

Rushayati B, Sunkar A, Hermawan R, Masganti, Meliani R. 2014. "Model Public Private Partnership dalam Mengatasi Degredasi dan Deforestasi Hutan." Laporan Penelitian. Bogor: Fakultas Kehutanan IPB.

Riyadi dan Deddy., 2005., Perencanaan Pembangunan Daerah: Strategi Menggali Potensi dalam Mewujudkan Otonomi Daerah. Jakarta: Gramedia Pustaka Utama.

Sutikno, Sigit, Rinaldi, Chairul, Ahmad Muhammad. 2017. Kajian Hidrologi Lanskap Giam Siak Kecil_Bukit Batu Kabupaten Bengkalis Provinsi Riau. Pekanbaru: UR Press

Soedjito, H. 2004. Pedoman Pengelolaan Cagar Biosfer. Jakarta: Komite Nasional MAB Indonesia. 
Sujianto, Adianto, Zulkarnaini, Dadang Mashur, Abdul Sadad, Hasim As'ari. 2016., Kajian Pengelolaan Kelembagaan Pemberdayaan Masyarakat Kawasan Cagar Biosfer Giam Siak Kecil-Bukit Batu di Provinsi Riau, LPPM Universitas Riau dan Balitbang Riau, Pekanbaru.

Sumaryadi, Nyoman., 2005., Perencanaan Pembangunan Daerah Otonom dan Pemberdayaan Masyarakat., Jakarta: Penerbit Citra Utama.

Syarif., Maryadi, 2013., Teori dan Model Pengembangan Kelembagaan Pendidikan Tinggi Islam., Jurnal Media Akademika, Vol. 28, No. 3.

Usman, Sunyoto. 2004., Pembangunan dan Pemberdayaan Masyarakat., Yogyakarta: Pustaka Pelajar.

Wasistiono, Sadu., 2007., Prospek Pengembangan Desa., Bandung: Fokusmedia.,

Wrihatnolo, Randy R. dan Riant Nugroho Dwijowijoto., 2007., Manajemen Pemberdayaan:

Sebuah Pengantar dan Panduan untuk Pemberdayaan Masyarakat., Jakarta: Elex Media Komputindo Gramedia.

Zainal. 2015. Akar Permasalahan Kebakaran Hutan Serta Solusi Dalam Penyelesaiannya (Studi Kasus Provinsi Riau). Prosiding Seminar Nasional Prodi Ilmu Pemerintahan Fisip Unikom: 258-277.

Zulkarnaini dan Evawani Elysa Lubis. 2018. Pemberdayaan Masyarakat dalam Pemanfaatan Ekosistem Rawa Gambut, Jurnal Kebijakan Publik, Vol. 9 No. 2. 